\title{
Long-Term Synaptic Depression in the Striatum: Physiological and Pharmacological Characterization
}

\author{
Paolo Calabresi, ${ }^{1,2}$ Roberto Maj,, Antonio Pisani, ${ }^{1}$ Nicola B. Mercuri, ${ }^{1}$ and Giorgio Bernardi ${ }^{1,2}$ \\ ${ }^{1}$ Clinica Neurologica, Dip. Sanità, II Università di Roma, 00173 Rome, Italy and 2IRCCS, Clinica S. Lucia, 00173 Rome, Italy
}

The effect of tetanic activation of corticostriatal glutamatergic fibers was studied in striatal slices by utilizing extracellular and intracellular recording techniques. Tetanic stimulation produced a long-term synaptic depression (LTD) ( $>2$ h) of both extracellularly recorded field potentials and intracellularly recorded EPSPs. LTD was not coupled with changes of intrinsic membrane properties of the recorded neurons. In some neurons, repetitive cortical activation produced a short-term posttetanic potentiation (1-3 min). Subthreshold tetanic stimulation, which under control condition did not cause LTD, induced LTD when associated with membrane depolarization. Moreover, LTD was not expressed in cells in which the conditioning tetanus was coupled with hyperpolarization of the membrane. Bath application of aminophosphonovalerate (30-50 $\mu \mathrm{M})$, an antagonist of NMDA receptors, did not affect the amplitude of the synaptic potentials and the expression of LTD. Striatal LTD was significantly reduced by the pretreatment of the slices with $30 \mu \mathrm{m}$ 2-amino-3-phosphonopropionic acid, an antagonist of glutamate metabotropic receptors. LTD was not blocked by bicuculline $(30 \mu \mathrm{M})$, a $\mathrm{GABA}_{\mathrm{A}}$ receptor antagonist. Scopolamine (3 $\left.\mu \mathrm{M}\right)$, an antagonist of muscarinic receptors, induced a slight, but significant, increase of the amplitude of LTD. Both SCH 23390 ( $3 \mu \mathrm{M}$ ), an antagonist of D1 dopamine (DA) receptors, and H-sulpiride (1 $\mu \mathrm{M})$, an antagonist of D2 DA receptors, blocked LTD. LTD was also absent in slices obtained from rats in which the nigrostriatal DA system was lesioned by unilateral nigral injection of 6-hydroxydopamine. In DA-depleted slices, LTD could be restored by applying exogenous DA (30 $\mu \mathrm{M})$ before the conditioning tetanus. In DA-depleted slices, LTD could also be restored by coadministration of SKF 38393 (3-10 $\mu \mathrm{M})$, a D1 receptor agonist, and of LY 171555 (1-3 $\mu \mathrm{M})$, a D2 receptor agonist. Application of a single class of DA receptor agonists failed to restore LTD. These data show that striatal LTD requires three main physiological and pharmacological conditions: (1) membrane depolarization and action potential discharge of the postsynaptic cell during the conditioning tetanus, (2) activation of glutamate metabotropic receptors, and (3) coactivation of 01 and D2 DA receptors. Striatal LTD may alter the output signals from the

Received Mar. 19, 1992; revised May 28, 1992; accepted May 29, 1992.

We thank Dr. G. Sancesario for the immunohistochemical controls and Mr. G. Gattoni and Mr. M. Tolu for their excellent technical assistance. We also thank Dr. R. Fariello and Dr. M. Buonamici (Farmitalia) for providing lesioned animals and for measuring turning behavior. This study was supported by CNR grants to P.C.

Correspondence should be addressed to Dr. Paolo Calabresi, Clinica Neurologica, Dip. Sanità, II Università di Roma, Via O. Raimondo, 00173 Rome, Italy. Copyright (c) 1992 Society for Neuroscience 0270-6474/92/124224-10\$05.00/0 striatum to the other structures of the basal ganglia. This form of synaptic plasticity can influence the striatal control of motor activity.

Use-dependent changes in synaptic efficacy have been widely studied in several neuronal systems in order to investigate the possible biochemical and biophysical mechanisms that underlie memory and learning. Repetitive stimulation of excitatory pathways in the brain results either in a persistent enhancement or in a permanent decrease of synaptic transmission. These changes have been termed long-term potentiation (LTP) (Kuba and Kumamoto, 1990) and long-term depression (LTD) (Ito, 1989). Since the hippocampus has been involved in processes such as learning and memory (Scoville and Milner, 1957; Green, 1964; Colemann and Lindsley, 1977; Teyler and Discenna, 1984), different authors have hypothesized that LTP in the hippocampus (Bliss and Lomo, 1973; Schwartzkroin and Wester, 1975; Morris et al., 1986) can represent the neural basis of some forms of memory. It has also been reported that in the hippocampal field CA1, LTD can be produced when a low-frequency test input is negatively correlated in time with a high-frequency conditioning input (Stanton and Sejnowski, 1989). In visual cortex, where long-term changes of synaptic transmission have been implicated in developmental plasticity (Artola and Singer, 1987), tetanic stimulation of excitatory pathways can induce either LTP or LTD depending on the level of depolarization of the postsynaptic neuron (Artola et al., 1990). Furthermore, models of cerebellar network functions have suggested that the parallel fiber-Purkinje neuron synapse could be modifiable as a consequence of climbing fiber activation (Marr, 1969; Albus, 1971). This property was first observed in the intact cerebellum as LTD of synaptic transmission between parallel fibers and Purkinje neurons following conjunctive stimulation of parallel fiber and climbing fiber inputs to Purkinje neurons (Ito et al., 1982; Kano and Kato, 1987, 1988). This phenomenon is now considered to be the basis of several forms of motor learning (Ito, 1989). More recently, cerebellar LTD has been demonstrated in slice (Sakurai, 1987; Crepel and Krupa, 1988) and in tissue culture (Hirano and Hagiwara, 1988). It has been recently confirmed, by utilizing positron emission tomography in humans (Seitz et al., 1990), that not only the cerebellum but also the basal ganglia are strongly involved in the storage of motor skills in the brain. In particular, the corticostriatal projection seems to play a major role in motor learning (Seitz et al., 1990). This pathway utilizes glutamate as a transmitter, and it is the main excitatory input to the striatum (Spencer, 1976; Reubi and Cuenod, 1979). The physiology and the pharmacology of the glutamatergic corticostriatal projection have been widely studied both in vivo(Kitai 
Table 1. Intrinsic membrane properties of striatal neurons measured before and after (10 min) tetanic stimulation of corticostriatal fibers

\begin{tabular}{lcc} 
& Pretetanus & Posttetanus \\
\hline Membrane potential $(\mathrm{mV}) n=30$ & $-85 \pm 6$ & $-86 \pm 7$ \\
Input resistance $(\mathrm{M} \Omega)$ ) $n=20$ & $46 \pm 13$ & $48 \pm 12$ \\
Action potential amplitude $(\mathrm{mV}) n=25$ & $91 \pm 9$ & $93 \pm 11$ \\
Action potential duration $(\mathrm{msec}) n=15$ & $1.1 \pm 0.3$ & $1.1 \pm 0.3$ \\
\hline
\end{tabular}

et al., 1976; Bishop et al., 1982; Herrling, 1985; Calabresi et al., 1990b; Wilson et al., 1990) and in vitro (Kita et al., 1984; Calabresi et al., 1987a,b, 1988a,b, 1990c; Cherubini et al., 1988; Kawaguchi et al., 1989). Some recent evidence (Garcia-Munoz ct al., 1991; Walsh, 1991) suggests that, under different conditions, long-term changes of corticostriatal synaptic transmission can be observed. However, at present, the effect of repetitive activation of corticostriatal glutamatergic pathway has not yet been fully investigated. Thus, we have studied whether tetanic stimulation of corticostriatal fibers induces long-term changes of striatal synaptic transmission. In addition, we have tried to characterize the physiological and the pharmacological mechanisms underlying possible long-term changes of synaptic transmission.

\section{Materials and Methods}

Preparation and maintenance of the slices. Male Wistar rats, weighing $150-200 \mathrm{gm}$, were used for the experiments. The preparation and maintenance of the slices have been described previously (Calabresi et al., 1987a, 1988a, 1990c, 1991). Briefly, coronal slices $(200-300 \mu \mathrm{m})$ were prepared from tissue blocks of the brain with the use of a vibratome. These coronal slices included the neostriatum and neocortex. A single slice was transferred to a recording chamber (vol, $0.5 \mathrm{ml}$ ) and submerged in a continuously flowing Krebs' solution $\left(36^{\circ} \mathrm{C}, 2-3 \mathrm{ml} / \mathrm{min}\right)$ gassed with $95 \% \mathrm{O}_{2}, 5 \% \mathrm{CO}_{2}$ mixture. The composition of the solution was (in mM) $126 \mathrm{NaCl}, 2.5 \mathrm{KCl}, 1.2 \mathrm{NaH}_{2} \mathrm{PO}_{4}, 1.2 \mathrm{MgCl}_{2}, 2.4 \mathrm{CaCl}_{2}, 11$ glucose, and $25 \mathrm{NaHCO}_{3}$.

Technique of recordings and stimulation parameters. Intracellular recording electrodes were filled with $2 \mathrm{M} \mathrm{KCl} \mathrm{(30-60} \mathrm{M \Omega ),} \mathrm{while} \mathrm{extra-}$ cellular electrodes were filled with $2 \mathrm{M} \mathrm{NaCl}(5-10 \mathrm{M} \Omega$ ). Intracellular and extracellular potentials were recorded with the use of an Axoclamp 2-A amplifier, displayed on an oscilloscope, and stored in a digital system. For synaptic stimulation, bipolar electrodes were used. These stimulating electrodes were located either in the cortical areas close to the recording electrode $(0.5-3 \mathrm{~mm})$ or in the white matter between the cortex and the striatum. In some experiments, a second stimulating electrode was located at approximately $90^{\circ}$ from the other stimulating electrode and the recording electrode (see Fig. 2). As conditioning tetanus, we used three trains $(3 \mathrm{sec}$ duration, $100 \mathrm{~Hz}$ frequency at $20 \mathrm{sec}$ intervals). The duration of each individual pulse was $0.01-0.3 \mathrm{msec}$. During tetanic stimulation, the intensity was increased to suprathreshold levels in the intracellular experiments and to levels producing the maximal amplitude of the field potential in the extracellular experiments (approximately twice the test intensity).

Data analysis and drug application. The field potential amplitude was defined as the average of the amplitude from the peak of the early positivity to the peak negativity, and the amplitude from the peak negativity to the peak late positivity (Alger and Teyler, 1976). Quantitative data on posttetanic modifications are expressed as a percentage of the controls, the latter representing the mean of responses recorded during a stable period (15-30 min) before tetanic stimulation. Posttetanic modifications are usually measured at 15-20 min from the tetanus. Values given in the text and in the figures are mean \pm SEM of changes in the respective cell populations. The Student's $t$ test was used to compare the means. Drugs were applied by dissolving them to the desired final concentration in the saline and by switching the perfusion from the control saline to drug-containing saline. Aminophosphonovalerate (APV), 2-amino-3-phosphonopropionic acid (AP3), bicuculline, dopamine (DA), LY 171555, SCH 23390, SKF 38393, scopolamine, and $l$-sulpiride were applied $15-20 \mathrm{~min}$ before the conditioning tetanus. In DA-depleted slices, within the first $5 \mathrm{~min}$ of application, DA and LY 171555 produced a decrease of the synaptic potentials (Calabresi et al., 1988a,b) and we had to increase the intensity of stimulation to obtain potentials of the same amplitude as those in the control medium.

Dopamine-depleting procedures and determination of the lesion of the dopaminergic system. To obtain unilateral nigrostriatal lesions, rats were injected with 6-hydroxydopamine (6-OHDA; $8 \mu \mathrm{g} / 4 \mu \mathrm{l}$ of saline containing $0.1 \%$ ascorbic acid) via a Hamilton syringe through a cannula inserted just rostral to the substantia nigra under stereotaxic coordinates (Paxinos and Watson, 1986): A, $3.7 \mathrm{~mm}$ anterior to the interaural line; $\mathrm{V}, 2.2 \mathrm{~mm}$ dorsal to the interaural line; $\mathrm{L}, 2.2 \mathrm{~mm}$ from the midline. Twenty days later, the rats were tested with $0.5 \mathrm{mg} / \mathrm{kg}$ (s.c.) apomorphine and the contralateral turns were recorded with automatic rotometers for $3 \mathrm{hr}$. Only those rats consistently making at least 200 contralateral turns were used for the electrophysiological studies. After brain dissection, we confirmed that the nigrostriatal pathway was lesioned. This was established by noting a greater than $95 \%$ loss of DA neurons in the substantia nigra compacta and the almost complete absence of DA terminals in the striatum. This was detected by an immunoperoxidase technique, which utilized a monoclonal antibody for tyrosine hydroxylase.

\section{Results}

\section{General characteristics of the recorded neurons}

These results are based on intracellular recordings from 101 striatal neurons, recorded from slices obtained from naive rats, and 32 cells, recorded from DA-depleted slices. In addition, extracellular experiments were performed on 78 slices obtained from naive rats and on 44 slices obtained from DA-lesioned animals. Although no intracellular staining of striatal cells was attempted in this study, it is probable that most impaled cells were medium spiny neurons because other studies reported that the majority of intracellularly stained cells in the striatum were of this type (Preston et al., 1980; Wilson and Groves, 1980; Misgeld et al., 1984; Kawaguchi et al., 1989). Intrinsic membrane properties of these cells have been previously described (Kita et al., 1984; Calabresi et al., 1987a,b, 1990c). The cells included in the data were selected on the basis of having a stable resting membrane potential. Membrane properties of these cells are reported in Table 1 . Spontaneous action potentials were not observed at rest, but the injection of positive current pulses triggered a tonic firing pattern. Intrinsic membrane properties of striatal neurons recorded from DA-depleted slices did not differ from those observed in naive cells.

\section{Effect of tetanic stimulation of corticostriatal fibers}

letanic stimulation (three trains: $3 \mathrm{sec}$ duration, $100 \mathrm{~Hz}$ frequency, 20 sec interval) of corticostriatal fibers produced a longlasting depression of both extracellularly and intracellularly recorded synaptic potentials (Fig. 1). In 21 neurons, intracellularly recorded, and in 20 extracellular experiments the recordings lasted more than $2 \mathrm{hr}$ and LTD persisted for the entire period of recording. In some neurons ( 31 out of 70 recorded cells), the LTD of intracellularly recorded EPSPs was preceded by a short- 


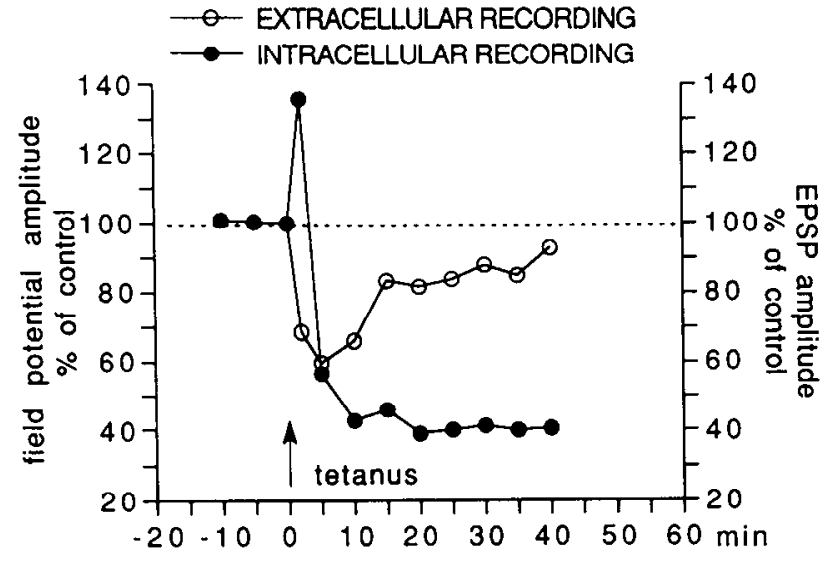

control
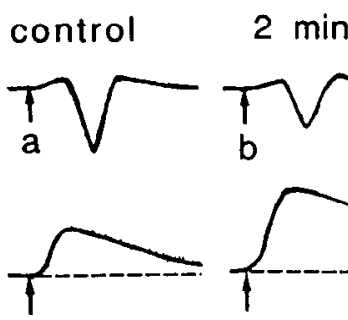

a
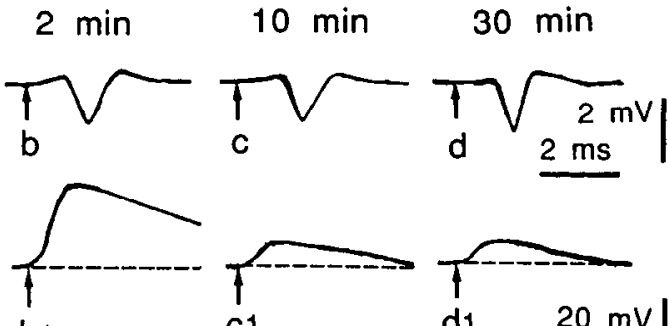

bl
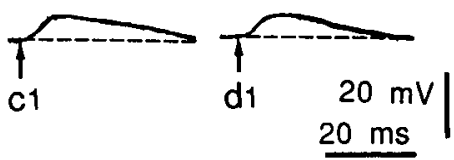

Figure 1. Effect of tetanic stimulation of corticostriatal fibers on the amplitude of field potentials and EPSPs recorded simultaneously from a striatal slice by utilizing two different electrodes. The graph in the upper part of the figure shows that the amplitude of extracellularly recorded field potentials (open circles) was decreased immediately after the tetanus; this decrease declined slightly in the first $15 \mathrm{~min}$ and then was stable through the entire period of recording (LTD). In contrast, the intracellularly recorded EPSP amplitude (solid circles) was increased within the first $2 \mathrm{~min}$, but then a persistent decrease of the EPSP amplitude was observed. The traces in the lower part of the figure represent the field potentials $(a-d)$ and the EPSPs $(a l-d l)$ obtained before $(a$ and $a I)$ and after ( $b-d$ and $b l-d I)$ the tetanus. The resting potential (RMP) of the intracellularly recorded neuron was $-86 \mathrm{mV}$, and it was constant through the experiment. In this and in the following figures, the traces of intracellularly and extracellularly recorded synaptic potentials are averages of four single sweeps.

term $(0.5-3 \mathrm{~min})$ posttetanic potentiation $(+31 \% \pm 11)$ (Fig. 1). This potentiation was usually not observed in extracellular experiments. In addition, in extracellular experiments the posttetanic depression decreased slightly within approximately 20 min after the tetanus; this event was usually not observed during intracellular recordings. In some experiments $(n=5)$, extracellular and intracellular potentials were simultaneously recorded (Fig. 1). The amplitude of the posttetanic depression measured 20 min after the tetanus was larger when detected by intracellular experiments $(-49 \% \pm 5 ; n=22)$ than when measured by extracellular experiments $(-23 \% \pm 3 ; n=45)$. A significant decrease of the half-decay time of the EPSP amplitude after the tetanus was observed only in a minority $(10 \%)$ of the recorded cells. It is important to stress that LTD was observed only when the intensity of stimulation was raised to cause suprathreshold EPSPs and repetitive action potential discharge was produced by tetanic activation. Similarly, field potentials of maximal amplitude during the tetanus were required LTD during extracellular experiments. Although we observed that in several cases different parameters of stimulation (i.e., 1-2 sec train duration


Figure 2. Input specificity of LTD. In the upper part of the figure is shown the experimental paradigm utilized to test the input specificity of the striatal LTD. Two stimulating electrodes were positioned in the white matter between the cortex and the striatum at about $90^{\circ}$ from the recording electrode. The distance between the stimulating electrodes and the recording site was $0.3-0.5 \mathrm{~mm}$; the distance between the two stimulating electrodes was $0.5-0.9 \mathrm{~mm}$. The intensity of stimulation of both of the stimulating electrodes was adjusted to evoke EPSPs of a similar amplitude. The tetanic stimulation was delivered only in one $(C O N D)$ of the two stimulating electrodes. The second stimulating electrode (TEST) was considered as a test electrode. The lower part of the figure shows the effect of the tetanus on the EPSPs evoked by these two stimulating electrodes. Note that the EPSP amplitude was clearly decreased when the conditioned pathway was stimulated (compare $a$ with $b$ ), while a much smaller effect was detected when the unconditioned pathway was stimulated (compare $c$ with $d$ ). RMP $=-84 \mathrm{mV}$.

and $50 \mathrm{~Hz}$ frequency) could also produce LTD of striatal synaptic transmission, we chose the parameters reported in Materials and Methods because they caused LTD in all the recorded slices. After the first induction, LTD could not be obtained a second time, even by increasing the intensity of stimulation to the control values (data not shown). LTD was not coupled with changes of intrinsic membrane properties of the recorded cell such as membrane potential, input resistance, and action potential amplitude and duration (Table 1).

\section{Input selectivity}

In some experiments $(n=10)$, we positioned two stimulating electrodes in the recorded slice. Both electrodes were localized in the white matter between the cortex and the striatum at about $90^{\circ}$ from the recording electrode that was located in the striatum (Fig. 2). The intensity of stimulation was adjusted to evoke FPSPs of the same amplitude from the two stimulating electrodes. The conditioning tetanus was delivered only by one of the two stimulating electrodes. As shown in Figure 2, a clear depression of the synaptic potential $(-51 \% \pm 6 ; n=10)$ was 


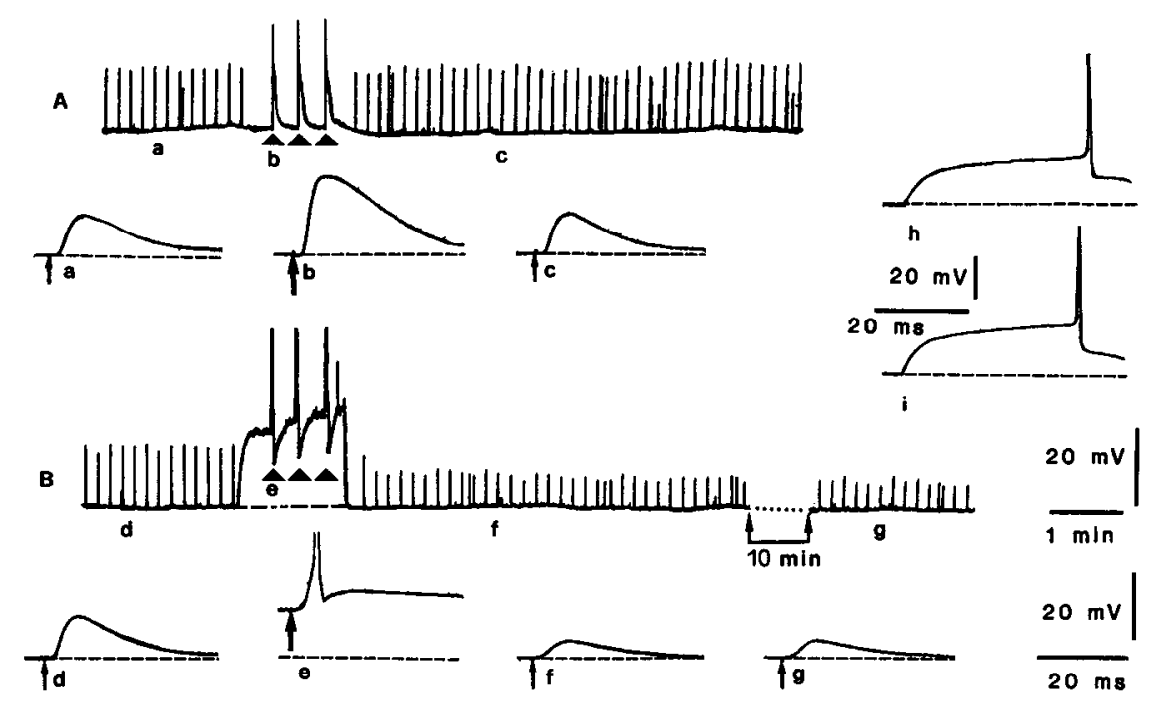

Figure 3. Effect of membrane depolarization on the expression of striatal LTD. A, In the upper part is shown the chart record of the membrane potential and the EPSP amplitude (upward deflections) of a striatal neuron recorded before $(a)$, during $(b)$, and after $(c)$ the tetanus. In the lower part, EPSPs are shown at higher sweep speed. During the tetanus, the intensity of the stimulation was raised slightly to produce EPSPs of increased amplitude, but not action potential discharge. Note that, under this condition, the tetanus did not cause permanent changes in the EPSP amplitude. $B$, In the same neostriatal cell, the tetanus was delivered during the depolarization of the membrane potential obtained by injecting constant depolarizing current $(+0.5 \mathrm{nA})$ into the recording electrode. In this case, the EPSP during the tetanus caused repetitive action potential activation $(e)$ and the tetanic stimulation produced LTD of synaptic transmission (compare $d$ with $f$ and $g$ ). The inset on the right part of the figure shows that in the same neuron the intrinsic membrane excitability, tested before $(h)$ and after $(i)$ tetanic stimulation by applying a depolarizing current pulse $(+1 \mathrm{nA})$, was not altered by the tetanus. $\mathrm{RMP}=-86 \mathrm{mV}$.

observed in the conditioned pathway, while a much smaller depression $(-15 \% \pm 5 ; n-10)$ was obtained in the unconditioned pathway.

\section{Effects of membrane polarizations on the expression of LTD}

In seven experiments, we studied the effect of membrane depolarization on the induction of LTD. Under control condition, tetanic stimulation of subthreshold EPSPs did not cause LTD (Fig. $3 A$ ). On the contrary, when tetanic stimulation of subthreshold EPSPs was coupled with membrane depolarization (approximately $+20 \mathrm{mV}$ ), obtained by injecting constant depolarizing current to cause action potential discharge during the tetanus (about $+0.5 \mathrm{nA})$, a persistent depression $(-48 \% \pm 5$; $n=7$ ) of synaptic potentials was observed (Fig. $3 B$ ). Membrane depolarization, in the absence of tetanic stimulation of corti- costriatal fibers, was not sufficient by itself to induce LTD ( $n=$ 5 ). In six experiments, we studied whether membrane hyperpolarization (approximately $-20 \mathrm{mV}$ ), obtained by injecting constant negative current (about $-1 \mathrm{nA}$ ), could prevent the expression of LTD of synaptic potential. When the tetanus was delivered at hyperpolarized membrane potential (Fig. $4 A$ ), it produced subthreshold EPSPs and did not cause LTD. On the contrary, when the same tetanus was delivered at resting membrane potential (Fig. $4 B$ ), it induced firing discharge and a significant LTD $(-48 \% \pm 6 ; n=6)$.

\section{APV and bicuculline on LTD}

The possible effect of APV, an NMDA receptor antagonist, on the expression of striatal LTD was studied in five intracellular experiments and in six extracellular experiments. As shown in
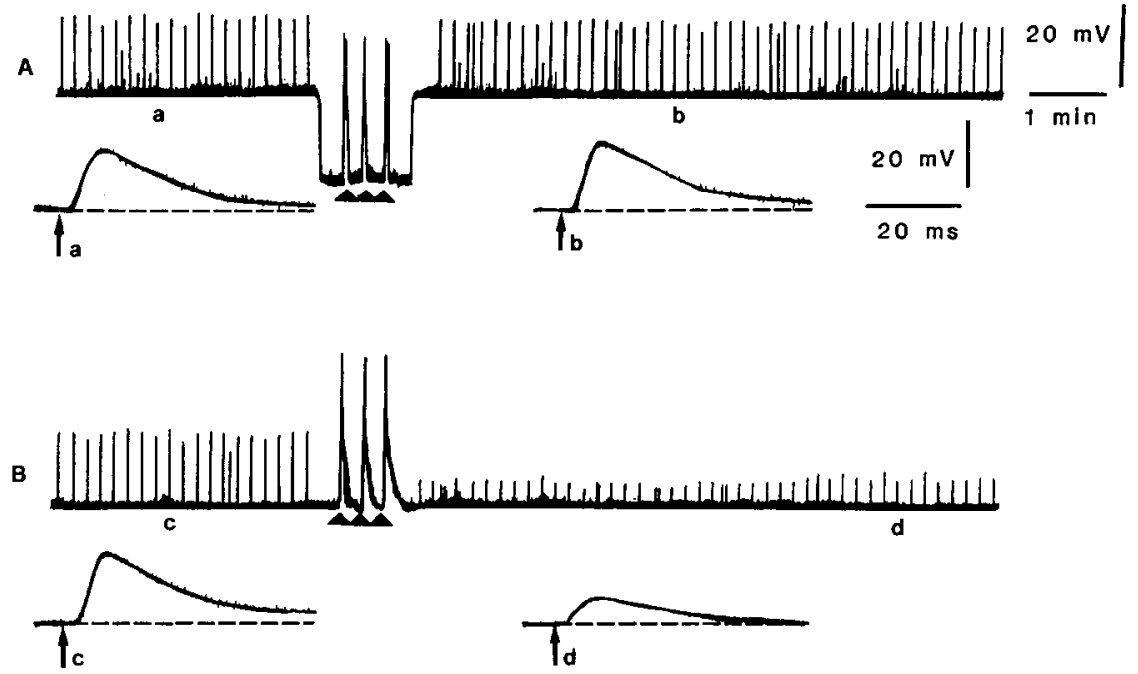
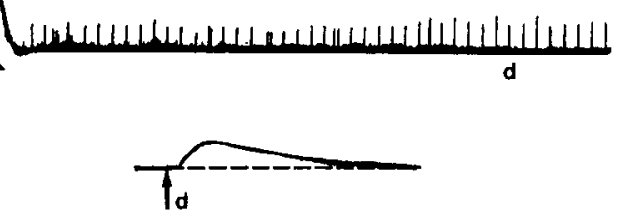

Figure 4. Effect of membrane hyperpolarization on the expression of LTD. $A$, In the upper part is shown the chart record of the membrane potential and of the EPSP amplitude (upward deflections) before $(a)$ and after $(b)$ tetanic stimulation. In the lower part EPSPs are shown at higher sweep speed. Constant hyperpolarizing current $(-1 \mathrm{nA})$ was injected into the recording electrode during the tetanic stimulation. Under this condition, the tetanus did not induce action potential discharge and did not produce LTD. $B$, In the same neuron, the tetanus was delivered at resting membrane potential $(-85 \mathrm{mV})$. In this case, the tetanus activated firing activity and the EPSP amplitude, recorded in control condition $(c)$, was clearly decreased after tetanic stimulation $(d)$. 
Figure 5. Blockade of NMDA receptors does not affect LTD. $A$, The trace is a chart record of the effect of $30 \mu \mathrm{M}$ APV (applied for the period indicated by the bar) on the EPSP amplitude (upward deflections) and on the posttetanic LTD. $B$, The traces show EPSPs recorded at higher sweep speed. Note that the EPSP amplitude recorded in control condition $(a)$ was not altered by APV (b). Although APV was present in the perfusion medium, tetanic stimulation produced a clear decrease of synaptic transmission $(c)$, and an increase of the intensity of stimulation $(d)$ was required to evoke EPSPs whose amplitude was similar to pretetanic values. $\mathrm{RMP}=-84 \mathrm{mV}$. $C$, The graph shows the posttetanic LTD observed in several extracellular experiments in control condition ( $n=24$; open circles) and in the presence of $50 \mu \mathrm{M}$ APV $(n=6$; open squares). Note that APV did not induce clear changes in the amplitude and in the duration of striatal LTD.
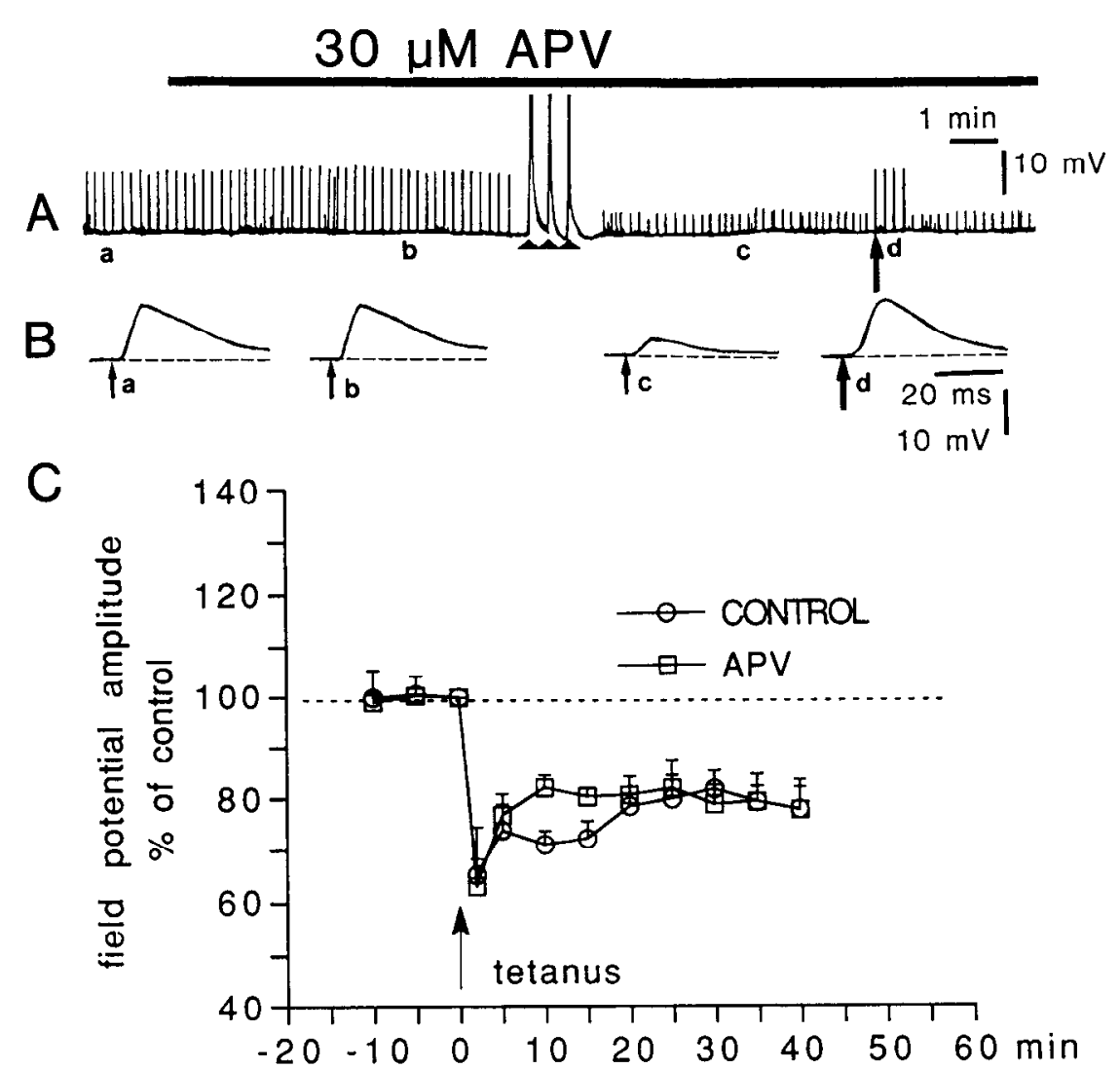

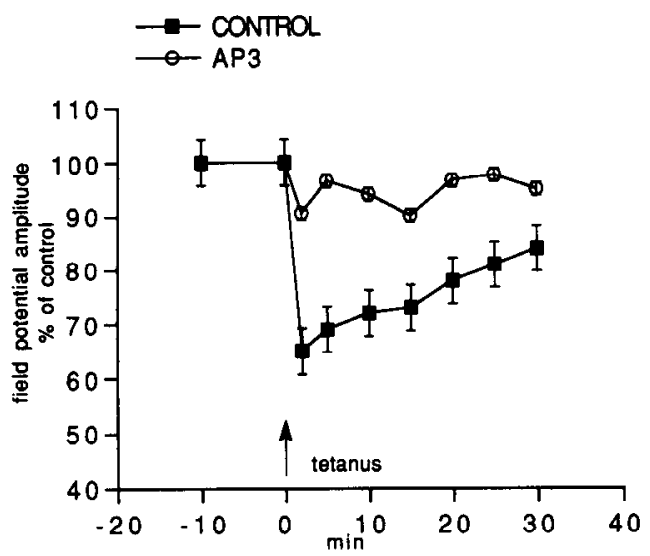

control
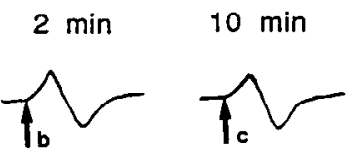

$30 \mathrm{~min}$


Figure 6. Blockade of glutamate metabotropic receptors significantly reduces striatal LTD. In the upper part of the figure, the graph shows the posttetanic LTD of field potentials recorded in slices maintained in control medium (solid squares; $n=12$ ) and in slices incubated (15-20 min before the tetanus) in $30 \mu \mathrm{M}$ AP3 (open circles; $n-6$ ). Note that the antagonist of glutamate metabotropic receptors greatly reduced LTD. The lower part of the figure shows an example of the inhibitory effect of AP3 on LTD. The slice was incubated ( $20 \mathrm{~min}$ before the tetanus) in $30 \mu \mathrm{M}$ AP3: $a$ shows the field potential recorded immediately before the tetanus, and $b-d$ represent the field potentials at different times after the tetanus.
Figure 5, $A$ and $B, A P V(30-50 \mu \mathrm{M})$, added to the external medium, did not cause changes in the amplitude and in the time course of intracellularly recorded EPSPs; in addition, incubation of the slices in APV did not prevent the induction of LTD $(-51 \% \pm 7 ; n=5)$. Figure $5 C$ also shows that in the extracellular experiments, APV $(50 \mu \mathrm{M})$ did not block the induction and the maintenance of striatal LTD. Bicuculline $(30 \mu \mathrm{M})$, a $\mathrm{GABA}_{\mathrm{A}}$

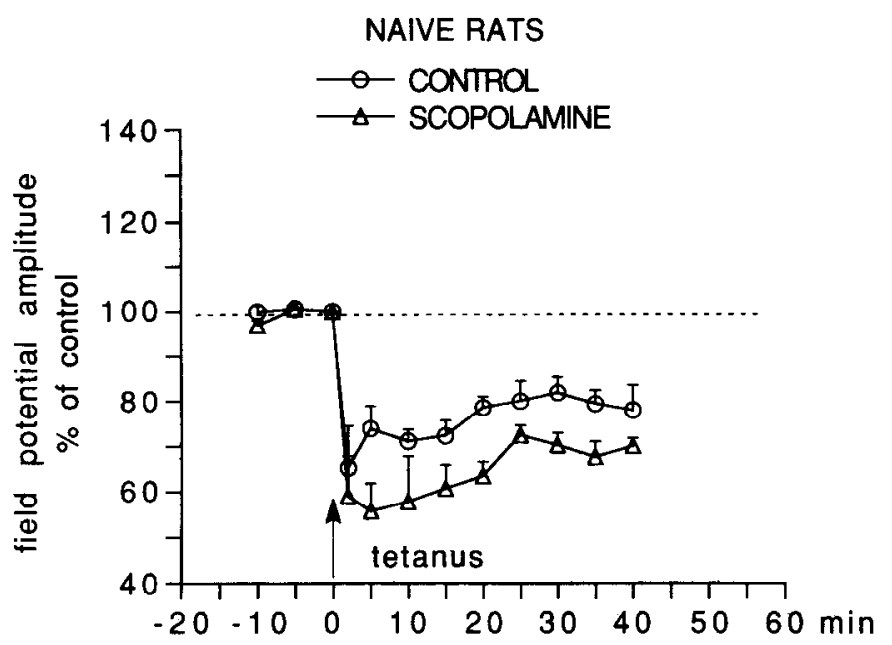

Figure 7. Scopolamine does not block the expression of striatal LTD. The graph shows the posttetanic depression of extracellularly recorded field potentials in control medium $(n=24$; open circles $)$ and in the presence of $3 \mu \mathrm{M}$ scopolamine ( $n=6$; open triangles) in the external medium. Note that this muscarinic antagonist did not block the expression of striatal LTD, but it slightly increased the amplitude of the posttetanic depression. 

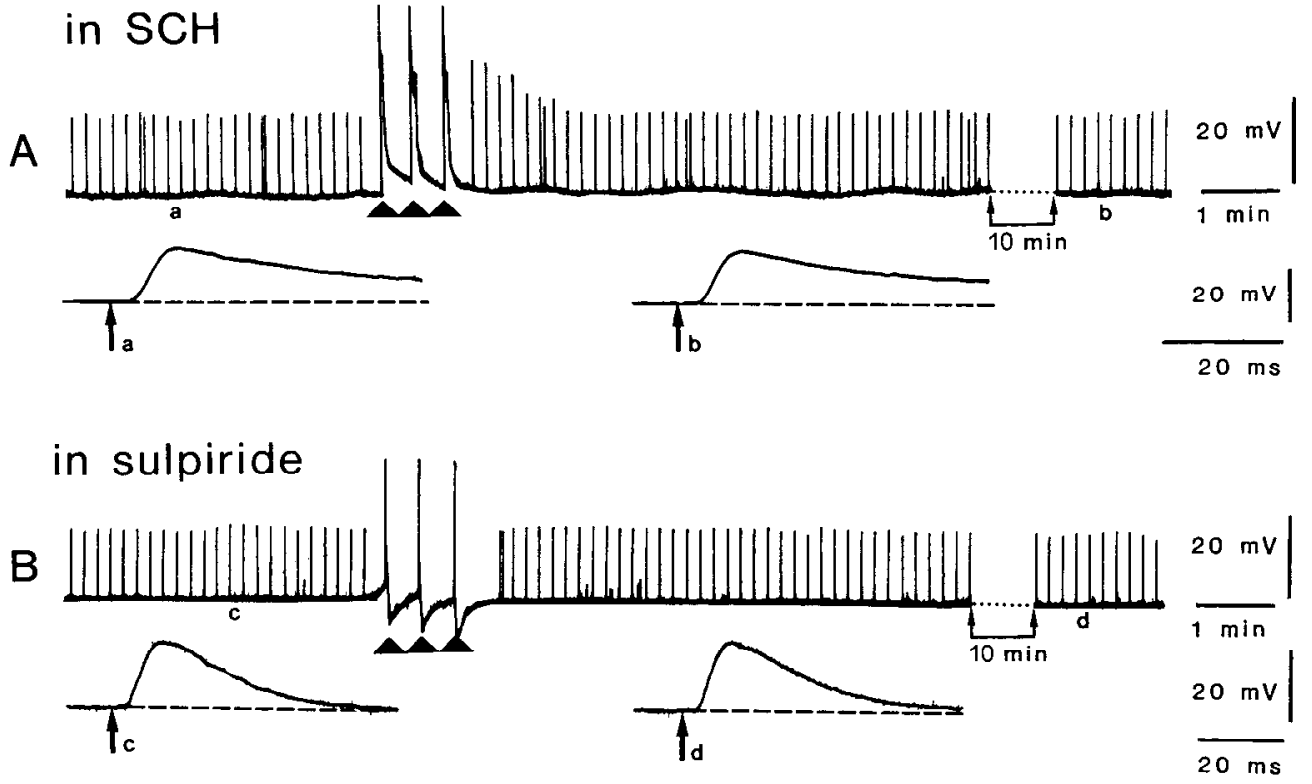

Figure 8. Both D1 and D2 DA receptor antagonists block LTD. $A$, The $u p$ per trace shows the chart record of the membrane potential and of the EPSP amplitude (upward deflection) before $(a)$ and after $(b)$ the tetanic stimulation of a cell recorded from a slice incubated in $3 \mu \mathrm{M} \mathrm{SCH} \mathrm{23390.} \mathrm{In} \mathrm{the} \mathrm{lower} \mathrm{part,}$ EPSPs are shown at higher sweep speed. Note that, in the presence of the D1 receptor antagonist, the tetanus induced only a brief posttetanic potentiation, but not LTD of synaptic transmission. RMP $=-86 \mathrm{mV} . B$, The upper trace shows the chart record of the membrane potential and of the EPSP amplitude (upward deflections) before (c) and after $(d)$ the tetanic stimulation of another cell recorded from a slice incubated in $1 \mu \mathrm{M} l$-sulpiride. In the lower part, EPSPs are shown at higher sweep speed. Note that, also in the presence of the D2 receptor antagonist, the tetanus did not induce LTD. RMP = $-83 \mathrm{mV}$ receptor antagonist, did not alter the amplitude of extracellularly (20 min after the tetanus: $-25 \% \pm 7 ; n=5$ ) and intracellularly (20 min after the tetanus: $-48 \% \pm 9 ; n-5$ ) recorded LTD.

\section{Effect of AP3 on striatal LTD}

A metabotropic subtype of glutamate receptor coupled with phosphoinositide hydrolysis has been characterized in the striatum and in other brain areas (Sladeczek et al., 1985, 1988; Calabresi et al., 1992). It has been recently shown that glutamate metabotropic receptors are involved in cerebellar (Linden et al., 1991) and hippocampal (Stanton et al., 1991) LTD. For this reason, we have tested the effect of AP3, an antagonist of glutamate metabotropic receptors, on the expression of striatal LTD. In basal condition, bath application of AP3 ( $30 \mu \mathrm{M}$; $n=6$ ), did not significantly alter EPSP and field potential amplitude and it did not affect membrane potential $(-86 \mathrm{mV} \pm$ $7 ; n=6$ ) and input resistance ( $47 \mathrm{M} \Omega \pm 14 ; n=5$ ) of the recorded cells. However, the incubation of the slices (15-20 min) in $30 \mu \mathrm{M}$ AP3 significantly reduced LTD evoked by tetanic stimulation (Fig. 6).

\section{Effect of scopolamine on $L T D$}

It has been shown that activation of muscarinic receptors causes depression of excitatory synaptic transmission in the striatum (Misgeld et al., 1986; Sugita et al., 1991). For this reason, we were interested to test whether the block of muscarinic receptors by scopolamine could influence striatal LTD. Figure 7 shows that, in six extracellular experiments, incubation of the slices in scopolamine $(3 \mu \mathrm{M})$ did not prevent LTD; on the contrary, a slight, but significant, increase of the LTD was observed (20 min after the tetanus: $-36 \% \pm 3$ ).

\section{Action of D1 and D2 DA receptor antagonists on striatal LTD}

DA plays a major role in the processing of information from the cortex to the striatum (Groves, 1983; Albin et al., 1989; Gerfen et al., 1990; Graybiel, 1990). Considering the possible interaction of the nigrostriatal DAergic system with the corticostriatal transmission, we studied the action of D1 and D2 DA receptor antagonists on the expression of striatal LTD. Figure $8 A$ shows that incubation of the slice in $3 \mu \mathrm{M} \mathrm{SCH} 23390(n=$
5), a Dl receptor antagonist, prevents the induction of LTD. A similar result was obtained by incubating the slices in $1 \mu \mathrm{M}$ $l$-sulpiride $(n=5)$, a D2 receptor antagonist (Fig. $8 B)$. As previously reported (Calabresi et al., 1987b, 1988a,b), both of these antagonists by themselves did not affect membrane potential, input resistance, and EPSP amplitude.

\section{Effect of unilateral DA lesion on LTD}

In order to investigate further the role of endogenous DA on the expression of striatal LTD, we tested whether the unilateral lesion of the nigrostriatal pathway caused by 6-OHDA (see Materials and Methods) could influence the expression of LTD in the ipsilateral striatum. As shown in Figure 9, cells recorded from DA-depleted striata did not show LTD $(n=6)$. The lack of LTD in DA-depleted slices was also observed in extracellular experiments (Fig. 10). In DA-lesioned animals, the study of the striatum contralateral to the lesion showed LTD similar to that observed in naive slices $(-49 \% \pm 7 ; n=6$; not shown).

\section{Dopamine agonists and LTD in DA-depleted slices}

In three cells recorded from DA-depleted slices, I.TD was restored after the incubation of the slices in $30 \mu \mathrm{M}$ DA (Fig. 9). DA produced by itself a decrease of synaptic potentials (Calabresi et al., 1988a). For this reason, after the incubation of the slices in DA, a slight increase of the intensity of stimulation was required to obtain EPSPs of the same amplitude as those in control condition. The capability of exogenous DA to restore LTD in DA-depleted slices was confirmed in extracellular experiments (Fig. 10). This effect of exogenous DA on depleted slices was antagonized either by $3 \mu \mathrm{M}$ SCH 23390 or by $1 \mu \mathrm{M}$ $l$-sulpiride (Fig. 10). When sulpiride was added to the DA-containing solution, not only a blockade of the LTD, but also a field potential enhancement, was observed (Fig. 10). We finally investigated whether application of a single class of DA receptors could restorc the ability to induce LTD in DA-depleted slices. Neither $10 \mu \mathrm{M}$ SKF $(n=4)$, a D1 receptor agonist, nor $3 \mu \mathrm{M}$ LY $171555(n=4)$, a D2 receptor agonist, alone could restore LTD. In contrast, LTD was restored after the coadministration of these two DA receptor agonists $(-53 \% \pm 12 ; n=4)$ even at lower concentrations ( $3 \mu \mathrm{M}$ and $1 \mu \mathrm{M}$, respectively; data not 

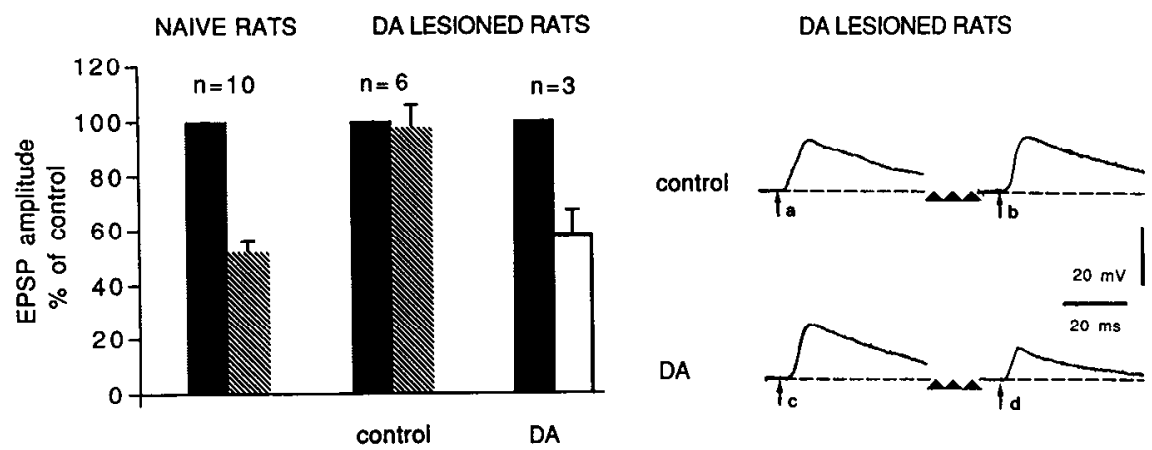

Figure 9. LTD is absent in DA-depleted slices. The graph in the left part of the figure shows the effect of tetanic stimulation on the EPSP amplitude in slices obtained from naive animals $(n=10 ;$ bars on the left), in slices obtained from 6-OHDA-lesioned animals $(n=6$; bars in the middle), and in slices obtained from 6-OHDA-lesioned animals but incubated in $30 \mu \mathrm{M}$ DA $(n=3$; bars on the right). Note that tetanic stimulation induced LTD in control slices, but not in DA-depleted slices. Incubation of the DA-depleted slices in $30 \mu \mathrm{M}$ DA restored LTD. The inset in the right part of the figure shows a cell recorded from a DA-depleted slice. The EPSP was recorded before $(a)$ and after $(b, 15$ min) the tetanus in control medium. In this condition, no LTD was observed. When the slice was incubated in $30 \mu \mathrm{M} \mathrm{DA}$, the EPSP recorded before (c) the tetanus was clearly decreased after $(d, 15 \mathrm{~min})$ tetanic stimulation. RMP $=-86 \mathrm{mV}$.

shown). LY 171555 , like DA, produced by itself a reduction of the evoked potentials; for this reason, after the first minutes of application of this drug, a slight increase of the intensity of stimulation was required to evoke synaptic potentials of the same amplitude as those in control condition. As previously reported (Calabresi et al., 1987b), DA, SKF 38393, and LY 171555 did not alter membrane potential and input resistance of striatal neurons.

\section{Discussion}

\section{LTD and glutamate receptors}

The present study shows that repetitive activation of the corticostriatal inputs produces LTD of excitatory synaptic transmission in the striatum. In the mammalian CNS, glutamate

\section{DA LESIONED}

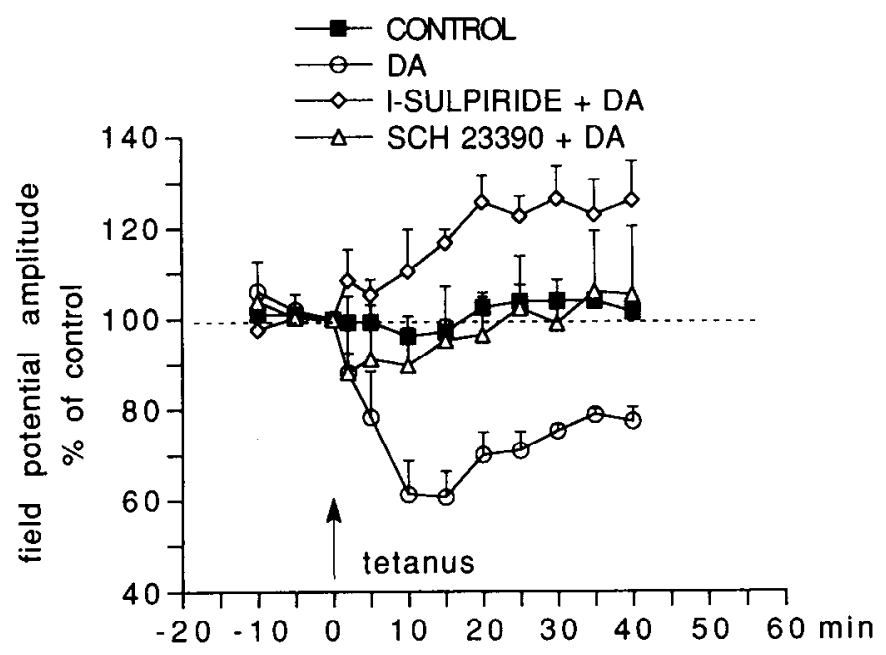

Figure 10. In DA-depleted slices, the effect of exogenous DA is blocked either by $S C H 23390$ or by $l$-sulpiride. The graph shows the effect of tetanic stimulation on the amplitude of field potentials recorded from DA-depleted slices. LTD was absent in DA-depleted slices $(n=12$; solid squares), but it was restored after the incubation of these slices in $30 \mu \mathrm{M}$ DA ( $n=10$; open circles). LTD was not observed when to the DA-containing medium was added either $3 \mu \mathrm{M} \mathrm{SCH} 23390(n=5$; open triangles) or $1 \mu \mathrm{M} l$-sulpiride ( $n=5$; open diamonds). binds to different subtypes of ionotropic and metabotropic receptors distinguished by their selective ligands (Watkins and Evans, 1981; Sladeczek et al., 1985, 1988). The quisqualate and kainate ionotropic receptors are lumped together as non-NMDA receptors because of the difficulty of separating them pharmacologically. Although activation of NMDA glutamate receptors in the striatum produces detectable electrophysiological effects (Calabresi et al., 1990a), excitatory synaptic transmission in the striatum is mainly mediated by the activation of non-NMDA glutamate receptors. This idea is supported by the following evidence: (1) striatal EPSPs are blocked either by kynurenic acid, a broad-spectrum antagonist of excitatory amino acids, or by 6-cyano-7-nitroquinoxaline-2,3-dione, a selective antagonist of non-NMDA glutamate receptors (Herrling, 1985; Cherubini et al., 1988; Calabresi et al., 1991, 1992; Sugita et al., 1991); (2) NMDA receptor antagonists do not affect, at least under control condition, the amplitude and the time course of striatal EPSPs (Cherubini et al., 1988; Calabresi et al., 1992).

We have shown that striatal LTD is not blocked by incubation of the slices in APV. This evidence indicates that activation of NMDA receptors is not required for the expression of striatal LTD.

Glutamate not only mediates fast synaptic transmission in the brain through the activation of ionotropic receptors, but also binds to metabotropic receptors linked to inositol phospholipid metabolism (Sladeczek et al., 1985). Agonists of metabotropic receptors mediate several physiological effects in different brain areas: modulation of potassium (Charpak et al., 1990) and calcium (Lester and Jahr, 1990) channels and reduction of synaptic transmission (Baskys and Malenka, 1991; Calabresi et al., 1992). Activation of metabotropic glutamate receptors is required for LTD in the cerebellum (Linden et al., 1991) and in the hippocampus (Stanton et al., 1991). We have found that AP3, an antagonist of metabotropic receptors, significantly reduces striatal LTD, suggesting that the activation of this glutamate receptor subtype is necessary for long-term changes of synaptic transmission in the striatum. A cascade of biochemical events may contribute to the permissive role of glutamate metabotropic receptors in the generation of striatal LTD: increased hydrolysis of phosphoinositides, production of the second messengers diacylglycerol and inositol 1,4,5-trisphosphate, and mobilization of intracellular calcium (Sladeczek et al., 1985, 1988). As we 
have hypothesized for DA receptors (see below), it is also possible that an increased release of arachidonic acid from striatal neurons (Dumuis et al., 1990) mediates the action of glutamate metabotropic receptors in the generation of striatal LTD.

\section{High frequency of stimulation is required for striatal LTD}

The frequency of stimulation necessary to induce LTD in the striatum is higher than that required to cause LTD in the cerebellum (Ito, 1989) and some forms of LTP in the hippocampus (Kuba and Kumamoto, 1990). Several reasons may account for this difference. First, in the striatum the synaptic excitation is rather sparse (Calabresi et al., 1989), and for this reason a synaptic stimulation at low frequencies may be too weak to trigger synchronous postsynaptic bursts necessary to induce LTD. Second, in contrast to Purkinje cells (Llinas and Sugimori, 1980) and to pyramidal hippocampal neurons (Wong and Traub, 1983), striatal neurons do not possess intrinsic bursting mechanisms (Calabresi et al., 1987a,b, 1989, 1990a-c, 1991): in the absence of these intrinsic membrane mechanisms, the striatum may require sustained presynaptic activation to express LTD. Third, differential morphological and electrical characteristics among dendritic spines of cerebellar and striatal neurons could be responsible for differences in synaptic potency (Wilson, 1984); for such a reason, the induction of LTD in these two types of cells may require different patterns of synaptic stimulation.

During membrane depolarizations, cortical neurons are able to fire at frequencies even higher than $100 \mathrm{~Hz}$ (Calvin and Sypert, 1976; Stafstrom et al., 1984). For this reason, we believe that our parameters of tetanic stimulation may mimick the "physiological" activity of the corticostriatal pathway.

The demonstration that intrinsic membrane properties of the recorded cells are not altered by tetanic stimulation rules out the possibility that LTD is caused by local neuronal damage. Furthermore, we have recently found that when magnesium is omitted in the external medium (to remove the NMDA channel voltage-dependent blockade), the same protocol of tetanic stimulation causes LTP rather than LTD (Calabresi et al., in press). This finding suggests that specific changes in synaptic functions are involved in striatal posttetanic plasticity.

\section{LTD is mainly expressed in the conditioned pathway}

Our data suggest that when a single group of presynaptic fibers was conditioned, LTD was mainly generated in the tetanizcd fibers and much less in the untetanized fibers, even though they terminated on the same postsynaptic neuron. This input specificity suggests that, although postsynaptic mechanisms may play an important role in the expression of striatal LTD, these mechanisms are selectively operating in the synaptic area conditioned by the tetanus, rather than in the whole postsynaptic neuron. The small decrease of the EPSP amplitude observed in the untetanized pathway can be explained by assuming that there is a degree of overlapping between the synapses activated by the conditioning electrode and those activated by the test electrode. Input specificity has also been reported for the hippocampal LTP (Bliss and Lomo, 1973; Schwartzkroin and Wester, 1975; Dunwiddie and Lynch, 1978; Yamamoto and Sawada, 1981).

\section{Membrane depolarization during the tetanus is required for I.TD}

Two main observations suggest that postsynaptic membrane depolarization and action potential discharge during the tetanus are required to induce LTD in the striatum: (1) the coupling of depolarizing current in the recorded neuron to tetanic stimulation induces LTD, even when the tetanized pathway, at resting membrane potential, produces subthreshold EPSPs that by themselves are not sufficient to cause LTD; (2) the induction of LTD is blocked by injection of hyperpolarizing current into the postsynaptic neuron.

In the visual cortex, the same tetanic stimulation can induce either LTP or LTD depending on the level of depolarization of the postsynaptic neuron (Artola et al., 1990). LTD is obtained if postsynaptic depolarization exceeds a critical level, but remains below a threshold that is related to NMDA receptorgated conductances, whereas LTP is induced if this second threshold is reached. This finding, taken together with our observations, suggests that mechanisms other than the activation of NMDA conductances are involved in the "priming" action of postsynaptic membrane depolarization in the expression of LTD in different brain structures.

\section{Modulation of striatal LTD}

In the present study, we have tested the possible involvement of different neurotransmitters in the generation of striatal LTD. In hippocampal and cortical neurons, the blockade of GABAergic inhibition influences the expression of long-term changes of synaptic transmission (Kuba and Kumamoto, 1990). We have found that bicuculline, a $\mathrm{GABA}_{\mathrm{A}}$ receptor antagonist, does not significantly affect the induction and the time course of striatal LTD. In the striatum, postsynaptic GABAergic inhibition is of short duration and hyperpolarizing IPSPs are not usually observed at resting level (Lighthall and Kitai, 1983; Calabresi et al., 1990c, 1991). The blockade of $\mathrm{GABA}_{\mathrm{A}}$ receptors does not cause membrane depolarization and does not cause spontaneous bursting activity in striatal neurons (Calabresi et al., 1989). These synaptic characteristics of the striatum may explain the inability of bicuculline to influence the striatal LTD.

Although muscarinic agonists produce a presynaptic reduction of excitatory transmission in the striatum (Misgeld et al., 1986; Sugita et al., 1991), incubation of the slices with scopolamine, a muscarinic antagonist, failed to block the generation of LTD. On the contrary, a slight but significant increase of the amplitude of LTD was observed when the slices were incubated in the medium containing this muscarinic antagonist. This finding may indicate that an endogenous cholinergic tone exerts a negative control on the expression of striatal LTD. This control may involve either presynaptic mechanisms (Sugita et al., 1991), or a postsynaptic regulation of calcium influx (Misgeld et al., 1986).

Pretreatment of the slices with either D1 or D2 DA receptor antagonists blocks the expression of LTD. This evidence indicates that coactivation of D1 and D2 DA receptors is required for this physiological event. The lack of LTD in DA-depleted slices is a further demonstration that endogenous DA is involved in the generation of striatal LTD. The ability to induce LTD, even in DA-depleted slices, after the application of exogenous DA or after the coadministration of D1 and D2 receptor agonists, indicates that this form of synaptic plasticity is not irreversibly lost after 6-OHDA-induced lesions. A cooperative role for D1 and D2 DA receptors has also been suggested by behavioral (Clark and White, 1987) and biochemical (Bertorello et al., 1990) studies. In Chinese hamster ovary cells, transfected with the D1 and D2 receptor complementary DNA, coactivation of these two DA receptors causes a marked synergistic potentiation of arachidonic acid release (Piomelli et al., 1991). 
Arachidonic acid exerts a long-term modulation of glutamatergic synaptic transmission (Drapcau ct al., 1990), and it may act as a retrograde messenger for presynaptic inhibition (Piomelli et al., 1987). For this reason, it is possible that DA-induced changes in the metabolism of arachidonic acid are involved in the striatal LTD. Another possible mechanism implicated in the DAergic control of the expression of striatal LTD involves the regulation of the class of genes known as immediate-early genes (IEGs) (Sheng and Greenberg, 1990). These genes are thought to couple short-term stimulus/response cascades to longterm changes in gene function. In the striatum, endogenous DA activate IEGs (Graybiel et al., 1990) and low-dose combination of D1 and D2 selective DA agonists causes the activation of IEGs in DA-depleted rat brains (Paul et al., 1990). These findings seem to suggest the idea that DA receptors via IEG regulation may contribute to striatal LID.

\section{Functional implication for striatal LTD}

The striatum plays a major role in the control of movement (Groves, 1983; Graybiel, 1990). Two main inputs to the striatum are implicated in this physiological control: the corticostriatal glutamatergic pathway and the nigrostriatal DAergic pathway. In the striatum, these two afferents converge on the medium spiny neurons, which are GABAergic inhibitory cells projecting to the output structures of the basal ganglia (pallidus and substantia nigra reticulata) (Groves, 1983; Graybiel, 1990). Here we have shown that repetitive cortical stimulation produces a long-term decrease of excitatory transmission in the striatum. This event requires (1) membrane depolarization, (2) activation of glutamate metabotropic receptors, and (3) coactivation of D1 and D2 DA receptors. Striatal LTD will decrease the activity of projecting GABAergic spiny neurons, and it will influence the output signals from the striatum to the other structures of the basal ganglia and the control of motor activity.

\section{References}

Albin RL, Young AB, Penney JB (1989) The functional anatomy of basal ganglia disorders. Trends Neurosci 12:366-375.

Albus JS (1971) A theory of cerebellar function. Math Biosci 10:2561 .

Alger BE, Teyler TJ (1976) Long term and short term plasticity in the CA1, CA3 and dentate regions of the hippocampal slice. Brain Res 110:463-480.

Artola A, Singer W (1987) Long-term potentiation and NMDA receptors in visual cortex. Nature 330:649-652.

Artola A, Brocher S, Singer W (1990) Different voltage-dependent thresholds for inducing long-term depression and long-term potentiation in slices of rat visual cortex. Nature 347:69-72.

Baskys A, Malenka RC (1991) Agonists at metabotropic glutamate receptors presynaptically inhibit EPSCs in neonatal rat hippocampus. J Physiol (Lond) 444:687-701.

Bertorello AM, Hopfield JF, Aperia A, Greengard P (1990) Inhibition by dopamine of $(\mathrm{Na}+\mathrm{K}) \mathrm{ATPase}$ activity in neostriatal neurons through D1 and D2 dopamine receptor synergism. Nature 347:386-388.

Bishop GA, Chang HT, Kitai ST (1982) Morphological and physiological properties of neostriatal neurons: an intracellular horseradish peroxidase study in the rat. Neuroscience 7:179-191.

Bliss TVP, Lomo T (1973) Long-lasting potentiation of synaptic transmission in the dentate area of the anaesthetized rabbit following stimulation of the perforant path. J Physiol (Lond) 232:331-356.

Calabresi P, Misgeld U, Dodt U (1987a) Intrinsic membrane properties of neostriatal neurons can account for their low level of spontaneous activity. Neuroscience 20:293-303.

Calabresi P, Mercuri NB, Stanzione P, Stefani A, Bernardi G (1987b) Intracellular studies on the dopamine-induced firing inhibition of neostriatal neurons in vitro: evidence for D1 receptor involvement. Neuroscience 20:757-771.
Calabresi P, Benedetti M, Mercuri NB, Bernardi G (1988a) Endogenous dopamine and dopaminergic agonists modulate synaptic excitation in neostriatum: intracellular studies from naive and catecholamine depleted rats. Neuroscience 27:145-157.

Calabresi P, Benedetti M, Mercuri NB, Bernardi G (1988b) Depletion of catecholamines reveals inhibitory effects of bromocriptine and lysuride on neostriatal neurones recorded intracellularly in vitro. Neuropharmacology 27:579-587.

Calabresi P, Benedetti M, Mercuri NB, Bernardi G (1989) Selective depression of synaptic transmission by tetanus toxin: a comparative study on hippocampal and neostriatal slices. Neuroscience 30:663670.

Calabresi P, De Murtas M, Mercuri NB, Bernardi G (1990a) Kainic acid on neostriatal neurons intracellularly recorded in vitro: electrophysiological evidence for differential neuronal sensitivity. J Neurosci 10:3960-3969.

Calabresi P, Mercuri NB, Stefani A, Bernardi G (1990b) Synaptic and intrinsic control of membrane excitability of neostriatal neurons. I. An in vivo analysis. J Neurophysiol 63:651-662.

Calabresi P, Mercuri NB, Bernardi G (1990c) Synaptic and intrinsic control of membrane excitability of neostriatal neurons. II. An in vitro analysis. J Neurophysiol 63:663-675.

Calabresi P, Mercuri NB, De Murtas M, Bernardi G (1991) Involvement of GABA systems in the feedback regulation of glutamate- and GABA-mediated synaptic potentials in rat neostriatum. J Physiol (Lond) 440:581-599.

Calabresi P, Mercuri NB, Bernardi G (1992) Activation of quisqualate metabotropic receptors reduces glutamate- and GABA-mediated synaptic potentials in the rat striatum. Neurosci Lett 139:41-44.

Calabresi P, Pisani A, Mercuri NB, Bernardi G (in press) Long-term potentiation in the striatum is unmasked by removing the voltagedependent magnesium block of NMDA receptor channels. Eur J Neurosci, in press.

Calvin WH, Sypert GW (1976) Fast and slow pyramidal tract neurons: an intracellular analysis of their contrasting repetitive firing properties in the cat. J Neurophysiol 39:420-434.

Charpak S, Gahwiler BH, Do KO, Knopfel T (1990) Potassium conductances in hippocampal neurons blocked by excitatory amino acids transmitters. Nature 347:765-767.

Cherubini E, Herrling PL, Lanfumey L, Stanzione P (1988) Excitatory amino acids in synaptic excitation of striatal neurones in vitro. $\mathbf{J}$ Physiol (Lond) 400:677-690.

Clark D, White FJ (1987) Review: D1 dopamine receptor-the search for a function: a critical evaluation of the D1/D2 dopamine receptor classification and its functional implications. Synapse 1:347-388.

Colemann JR, Lindsley DB (1977) Behavioural and hippocampal electrical changes during opcrant learning in cats and effects of stimulating two hypothalamic-hippocampal systems. Electroencephalogr Clin Neurophysiol 42:309-331.

Crepel F, Krupa M (1988) Activation of protein kinase $C$ induces a long-term depression of glutamate sensitivity of cerebellar Purkinje cells. An in vitro study. Brain Res 458:397-401.

Drapeau C, Pellerin L, Wolfe LS, Avoli M (1990) Long-term changes of synaptic transmission induced by arachidonic acid in the CA1 subfield of the rat hippocampus. Neurosci Lett 115:286-292.

Dumuis A, Pin JP, Oomagari K, Sebben M, Bockaert J (1990) Arachidonic acid released from striatal neurons by joint stimulation of ionotropic and metabotropic quisqualate receptors. Nature 347:182184.

Dunwiddie TV, Lynch G (1978) Long-term potentiation and depression of synaptic responses in the rat hippocampus: localization and frequency dependency. J Physiol (Lond) 276:353-367.

Garcia-Munoz M, Young SJ, Groves PM (1991) Long-term potentiation and depression of the excitability of the corticostriatal terminal field. Soc Neurosci Abstr 19:533.

Gerfen CR, Engber TM, Mahan LC, Susel Z, Chase TN, Monsma FJ, Sibley DR (1990) D1 and D2 dopamine receptor-regulated gene expression of striatonigral and striatopallidal neurons. Science 250 : 1429-1432.

Graybiel AM (1990) Neurotransmitters and neuromodulators in the basal ganglia. Trends Neurosci 13:244-254.

Graybiel AM, Moratalla R, Robertson HA (1990) Amphetamine and cocaine induce drug-specific activation of the c-fos gene in striosomematrix and limbic subdivisions of the striatum. Proc Natl Acad Sci USA 87:6912-6916. 
Green JD (1964) The hippocampus. Physiol Rev 44:561-608.

Groves PM (1983) A thcory of the functional organization neostriatum and the neostriatal control of voluntary movement. Brain Res Rev $5: 109-132$.

Herrling PL (1985) Pharmacology of the corticocaudate excitatory postsynaptic potential in the cat: evidence for its mediation by quisqualate- or kainate receptors. Neuroscience 14:417-426.

Hirano T, Hagiwara S (1988) Synaptic transmission between rat cerebellar granule and Purkinje cells in dissociated cell culture: effects of excitatory-amino acid transmitter agonists. Proc Natl Acad Sci USA 85:934-938.

Ito M (1989) Long-term depression. Annu Rev Neurosci 12:85-102.

Ito $\mathbf{M}$, Sakurai $\mathbf{M}$, Tongroach $\mathbf{P}$ (1982) Climbing fibre induced depression of both mossy fibre responsiveness and glutamate sensitivity of cerebellar Purkinje cells. J Physiol (Lond) 324:113-134.

Kano M, Kato M (1987) Quisqualate receptors are specifically involved in cerebellar synaptic plasticity. Nature 325:276-279.

Kano M, Kato M (1988) Mode of induction of long-term depression at parallel fibre-Purkinje cell synapses in rabbit cerebellar cortex. Neurosci Res 5:544-556.

Kawaguchi Y, Wilson CJ, Emson PC (1989) Intracellular recording of identified neostriatal patch and matrix spiny cells in a slice preparation preserving cortical inputs. J Neurophysiol 62:1052-1068.

Kita T, Kita K, Kitai ST (1984) Passive electrical membrane properties of rat neostriatal neurons in vitro slice preparation. Brain Res 300: 129-139.

Kitai ST, Kocsis JD, Preston RJ, Sugimori M (1976) Monosynaptic inputs to caudate neurons identified by intracellular injection of horseradish peroxidase. Brain Res 109:601-606.

Kuba K, Kumamoto E (1990) Long-term potentiations in vertebrate synapses: a variety of cascades with common subprocesses. Prog Neurobiol 34:197-269.

Lester RAJ, Jahr CE (1990) Quisqualate receptor mediated depression of calcium currents in hippocampal neurons. Neuron 4:741-749.

Lighthall JW, Kitai ST (1983) A short duration GABAergic inhibition in identified neostriatal spiny neurons: an in vitro slice study. Brain Res Bull 11:103-110.

Linden DJ, Dickinson MH, Smeyne M, Connor JA (1991) A longterm depression of AMPA currents in cultured cerebellar Purkinje neurons. Neuron 7:81-89.

Llinas RR, Sugimori M (1980) Electrophysiological properties of in vitro Purkinje cell dendrites in mammalian cerebellar slices. J Physiol (Lond) 305:197-213.

Marr D (1969) A theory of cerebellar cortex. J Physiol (Lond) 202: $437-470$.

Misgeld U, Frotscher M, Dodt U (1984) Identification of projecting neurons in rat neostriatal slices. Brain Res 299:367-370.

Misgeld U, Calabresi P, Dodt U (1986) Muscarinic modulation of calcium dependent plateau potentials in rat neostriatal neurons. Pfluegers Arch Physiol 407:482-487.

Morris RGM, Anderson E, Lynch GS, Baudry M (1986) Selective impairment of learning and blockade of long-term potentiation of an $N$-methyl-D-aspartate receptor antagonist, AP5. Nature 319:774-776.

Paul ML, Graybiel AM, Robertson HA (1990) Synergistic activation of the immediate-early gene c-fos in striosomes by D1- and D2selective dopamine agonists. Soc Neurosci Abstr 16:954.

Paxinos G, Watson C (1986) The rat brain in stereotaxic coordinates. Sydney: Academic.

Piomelli D, Volterra A, Dale N, Siegelbaum SA, Kandel ER, Schwartz JH, Berlardetti F (1987) Lipoxygenase metabolites of arachidonic acid as second messengers for presynaptic inhibition of Aplysia sensory cells. Nature 328:38-43.

Piomelli D, Pilon C, Giros B, Sokoloff P, Martres M, Schwartz J (1991) Dopamine activation of the arachidonic acid cascade as a basis for D1/D2 receptor synergism. Nature 353:164-167.

Preston RJ, Bishop GA, Kitai ST (1980) Medium spiny neuron pro- jection from the rat striatum: an intracellular horseradish peroxidase study. Brain Res 183:253-258.

Reubi JC, Cuenod M (1979) Glutamate release in vitro from corticostriatal terminal. Brain Res 176:185-188.

Sakurai M (1987) Synaptic modification of parallel fibre-Purkinje cell transmission in in vitro guinea-pig cerebellar slices. J Physiol (Lond) 394:463-480

Schwartzkroin PA, Wester K (1975) Long-lasting facilitation of synaptic potential following tetanization in the in vitro hippocampal slice. Brain Res 89:107-119.

Scoville WB, Milner B (1957) Loss of recent memory after bilateral hippocampal lesions. J Neurol Neurosurg Psychiatry 20:11-21.

Seitz RJ, Roland PE, Bohm C, Greitz T, Stone-Elander S (1990) Motor learning in man: a positron emission tomographic study. Neuroreport $1: 17-20$.

Sheng M, Greenberg ME (1990) The regulation and function of c-fos and other immediate-early genes in the nervous system. Neuron 4: $477-485$.

Sladeczek F, Pin JP, Recasens M, Bockaert J, Weiss S (1985) Glutamate stimulates inositol phosphate formation in striatal neurones. Nature 317:717-719.

Sladeczek F, Recasens M, Bockaert J (1988) A new mechanism for glutamate receptor action: phosphoinositide hydrolysis. Trends Neurosci 11:545-549.

Spencer HJ (1976) Antagonism of cortical excitation of striatal neurons by glutamic acid diethyl ester: evidence for glutamic acid as an excitatory transmitter in the rat striatum. Brain Res 102:91-101.

Stafstrom CE, Schwindt C, Crill WE (1984) Repetitive firing in layer $\mathrm{V}$ neurons from cat neocortex in vitro. J Neurophysiol 52:264-277.

Stanton PK, Sejnowski TJ (1989) Associative long-term depression in the hippocampus induced by Hebbian covariance. Nature 339: 215-218.

Stanton PK, Chattarji S, Sejnowski T (1991) 2-Amino-3-phosphonopropionic acid, an inhibitor of glutamate-stimulated phosphoinositide turnover, blocks induction of homosynaptic long-term depression, but not potentiation, in rat hippocampus. Neurosci Lett 127: 61-66.

Sugita S, Uchimura N, Jiang ZG, North RA (1991) Distinct muscarinic receptors inhibit release of GABA and excitatory amino acids in mammalian brain. Proc Natl Acad Sci USA 88:2608-2611.

Teyler TJ, Discenna P (1984) Long-term potentiation as a candidate mnemonic device. Brain Res Rev 7:15-28.

Walsh JP (1991) Long-term potentiation (LTP) of excitatory synaptic input to medium spiny neurons of the rat striatum. Soc Neurosci Abstr 20:334.

Walsh JP, Hull CD, Levine MS, Buchwald NA (1989) Kynurenic acid antagonizes the excitatory synaptic postsynaptic potential elicited in neostriatal neurons in the in vitro slice of the rat. Brain Res 480:290 293.

Watkins JC, Evans RH (1981) Excitatory amino acid transmitters. Annu Rev Pharmacol Toxicol 21:165-204.

Wilson CJ (1984) Passive cable properties of dendritic spines and spiny neurons. J Neurosci 4:281-297.

Wilson CJ, Groves PM (1980) Fine structure and synaptic connections of the common spiny neuron of the rat neostriatum. A study employing intracellular injection of horseradish peroxidase. J Comp Neurol 194:599-615.

Wilson CJ, Chang HT, Kitai ST (1990) Firing patterns and synaptic potentials of identified giant aspiny interneurons in the rat neostriatum. J Neurosci 10:508-519.

Wong RKS, Traub RD (1983) Synchronized burst discharge in disinhibited hippocampal slices. I. Intitiation in CA2-CA3 region. J Neurophysiol 49:442-457.

Yamamoto C, Sawada S (1981) Important factors in induction of longterm potentiation in thin hippocampal sections. Exp Neurol 74:122130. 